\title{
Calcareous nannofossil biostratigraphy of an outcrop section of Aptian sediments of west-central Portugal (Lusitanian Basin)
}

\author{
RUI O. B.P. DA GAMA ${ }^{1, *}$, PAUL R. BOWN ${ }^{2} \&$ M. CRISTINA CABRAL ${ }^{3}$ \\ ${ }^{1}$ Shell International Exploration and Production B.V. Kessler Park 1, 2288 GS Rijswijk, The Netherlands \\ ${ }^{2}$ Department of Geological Sciences, University College London Gower Street, London WC1E 6BT, UK \\ ${ }^{3}$ Faculty of Sciences, University of Lisbon, Centro de Geologia Campo Grande, C6, $4^{\circ}, 1749-016$, Lisboa, Portugal \\ ${ }^{*}$ Corresponding author (e-mail: robpdg@yahoo.co.uk)
}

\begin{abstract}
The present work is the first study of nannofossils from the Ponta Alta and Praia da Lagoa members of the Cresmina Formation and provides a new approach to establishing the age of these sediments. Nannofossil biostratigraphy improves previous age assignments: the Ponta Alta Member is placed within the latest Early Aptian, the passage between the Ponta Alta to the Praia da Lagoa members is assigned an early Late Aptian age and the Praia da Lagoa member is assigned an age not younger than the early Late Aptian. The lower half of the Rodísio Formation is assigned an age not younger than the Albian.

The integration of the nannofossil results with isotope stratigraphy provides support for the age attributions and calibration with more open-marine sections. The low abundance of nannoconids observed within the Ponta Alta Member coincides with the OAE 1a carbon isotope excursion and is possibly a manifestation of the 'nannoconid crisis' event. The subsequent increase in the abundance of nannoconids in the upper Ponta Alta Member coincides with the highest values of the $\delta^{13} \mathrm{C}$ isotope anomaly and may reflect a position above the 'nannoconid crisis' event in the early Late Aptian. J. Micropalaeontol. 28(2): 153-160, November 2009.
\end{abstract}

KEYWORDS: Aptian, biostratigraphy, calcareous nannofossils, Portugal, Lusitanian Basin

\section{INTRODUCTION}

The Lower Cretaceous São Julião section is located on the western coastline of Portugal, approximately $40 \mathrm{~km}$ to the NW of Lisbon (Fig. 1). It has been the subject of stratigraphical studies, focusing on lithostratigraphy, biostratigraphy, palaeontology, micropalaeontology and microfacies (Rey, 1972; Heimhofer et al., 2007) and chemostratigraphy (Burla et al., 2008). The present work is the first study of nannofossils from the Cresmina Formation and aims to provide alternative approaches to age determination and interpretations of the palaeoenvironment of deposition for these sediments. The results are calibrated with documented stratigraphical markers (Rey, 1972; Berthou \& Leereveld, 1990; Heimhofer et al., 2007) and are integrated with the carbon-isotope stratigraphy described in Burla et al. (2008) for the same section.

\section{GEOLOGICAL AND STRATIGRAPHICAL SETTING}

The study area is located in the southern zone of the Lusitanian Basin in west-central Portugal (Fig. 1). In the Lisbon region, Lower Cretaceous sediments are mostly composed of continental and marginal-marine facies, with rare, more open-marine episodes, reflecting frequent, small-scale coastline shifts (e.g. Ramalho, 1971; Rey, 1972, 1992; Berthou, 1973, 1984). By Late Aptian-Early Albian times most of the area was emergent, and thick units of fluvial sandstones were deposited (the traditional 'Grés superiores de Almargem' formation of Choffat (1885); Almargem/Rodízio Formations in Rey (1992)). These were overlain by fossiliferous marly-limestone successions of lagoonal to open-marine environments evidencing a marked transgressive phase, gradually recorded from the west towards the east in the Lisbon region, and from SW to NE over the whole of the basin, reaching its peak in the Cenomanian (e.g. Berthou, 1973, 1984).
Due to the lack, or rarity of ammonites, the stratigraphical framework of the Cretaceous of the Lisbon region is based upon regional integration of data from different fossil groups, namely benthic foraminifera, ostracods, dinocysts and rudists, coupled with field relationships, as summarized by Berthou (1984). As shown in Figure 2, the part of the S. Julião section under study encompasses deposits from the Ponta Alta (below) and Praia da Lagoa (above) members of the Cresmina Formation (Rey, 1992). These members were previously known as the 'Calcários recifais superiores' and 'Margas com ostras', respectively (Rey, 1972, 1979, 1984). For these units, the lithostratigraphical descriptions and the stratigraphical data allowing their age constraint are as follows.

- The Ponta Alta Member/'Calcários recifais superiores’ unit is mainly composed of limestones (base), reefal limestones (middle), Orbitolina marly limestones, interbedded Orbitolina marls and limestones and marls (top). This unit yields a rich fossil content, including the foraminifera species Palorbitolina lenticularis (Blumenbach) and Choffatella decipiens Schlumberger, an association that indicates an Early Aptian age (Rey, 1972). The Early Aptian age is also supported by the ostracod fauna described by Cabral (pers. comm.). In addition, Berthou \& Leereveld (1990) have described a dinocyst assemblage from the 'Calcários recifais superiores' from the nearby equivalent Rio de Mouro section, including Kleithriasphaeridium eoinodes, Kiokansium hesperum and Pseudoceratium securigerum, which is characteristic of the Early Aptian, However, Leereveld (in Berthou \& Leereveld, 1990) suggests that it may reach the earliest Late Aptian. Moreover, Heimhofer et al. (2007) confirmed the Early Aptian age based on the occurrences of the rudist species Pachytraga paradoxa, Praecaprina varians and Caprina douvillei. 


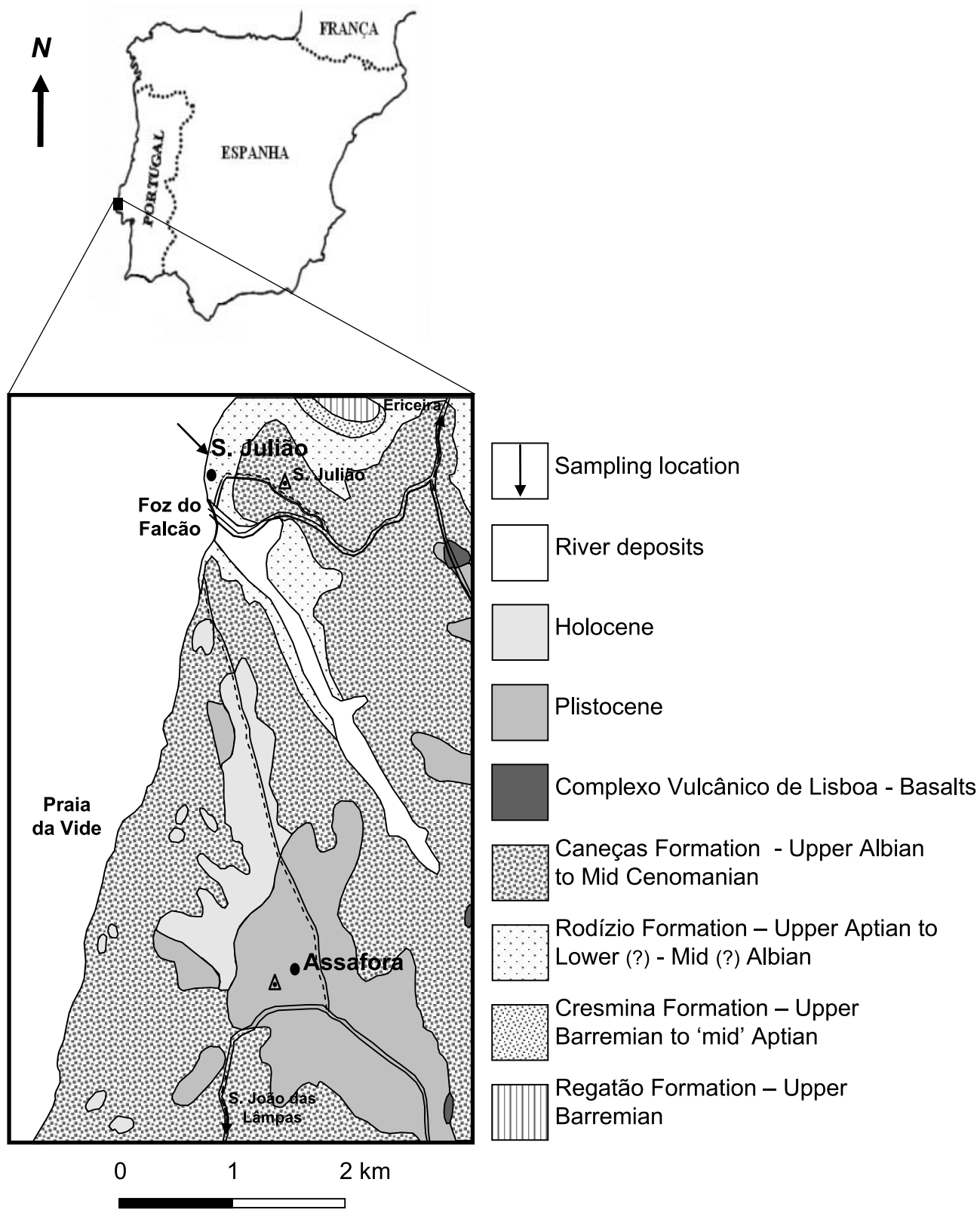

Fig. 1. Location of the S. Julião section, with simplified geology.

- The Praia da Lagoa Member/'Margas com ostras' unit is composed mainly of marls (base), oyster limestones and marls (middle), sandstones and dolostone (top). This unit is also rich in Palorbitolina lenticularis and Choffatella decipiens (Rey, 1972), which date it as Early Aptian. The ostracods from this same São Julião unit (Cabral, pers. comm.) and also from the Rio de Mouro section (Cabral \& Colin, 1998) confirm this age attribution. Pereira \& Cabral (2005) have recently described the charophyte assemblage from the Rio de Mouro section, reinforcing the previous age assignments. In addition, Heimhofer et al. (2007) also attributed an Early Aptian age for these sediments based on the occurrences of several age-diagnostic dinoflagellate cysts, including Ctenidodinium elegantulum, Callaiosphaeridium trycherium and Heslertonia heslertonensis. The dinocyst assemblage described by Berthou \& Leereveld (1990) for Rio de Mouro includes, besides the taxa mentioned for the underlying limestones, representatives of the Cyclonephelium compactum Group towards the top of the unit, suggesting the presence of the base of the Upper Aptian. Thus, the Praia da Lagoa Member /'Margas com ostras' unit has been assigned to the Lower Aptian or, maybe, to the Lower-lower Upper Aptian interval.

- The studied units are overlain by sandstones of the 'Grés superiores de Almargem' (Rodízio Formation in Rey, 1992) which, based on dinocysts, range in age from the Late Aptian to the Middle Albian (Berthou et al., 1981; Berthou \& Hasenboehler, 1982; Berthou, 1984; Berthou \& Leereveld, 1986; 1990). In addition, the dinocyst studies of Hasenboehler (1981), Dinis \& Trincão (1995) and Heimhofer et al. (2007) attributed the Rodízio Formation to the Albian. 


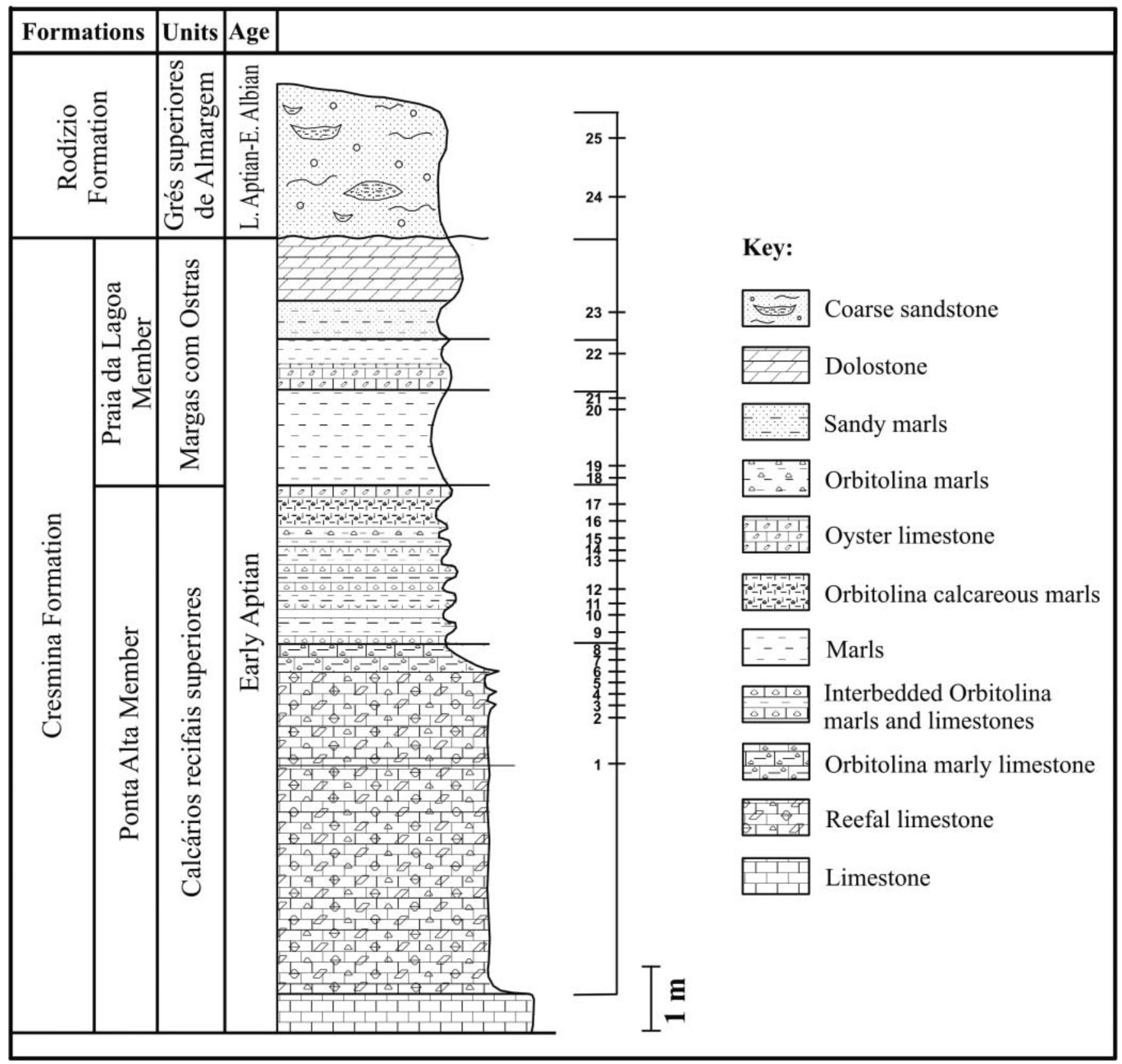

Fig. 2. Stratigraphical column of the S. Julião section indicating sampling and facies.

The presence of reefal limestones and interbedded Orbitolina marls and limestones indicates a shallow-marine environment for the deposition of the Cresmina Formation (Rey, 1972).

\section{MATERIALS AND METHODS}

A total of 25 nannofossil analyses were carried out (Fig. 2) and the sampling interval was approximately $30-40 \mathrm{~cm}$.

Calcareous nannofossil preparations were undertaken using simple smear slides and studied using standard light microscopy techniques (e.g. Bown \& Young, 1998). To provide the best possible representation of the preserved assemblages, nannofossil slides were semi-quantitatively examined and the resulting nannofossil abundances were divided into three groups: present, rare and common.
In this study, due to the fast-changing depositional environment and the dynamics of shallow-marine settings, particular emphasis is placed on the potential for re-deposition of "older" nannofossils into younger assemblages. Reworked occurrences were extremely rare, e.g. Lithraphidites bollii (samples 8 and 19) and Tubodiscus jurapelagicus (samples 7, 8 and 17).

The palaeobiogeographical position of Iberia during the Aptian and the recovered nannofossil assemblages (Fig. 3) permit the use of Tethyan biostratigraphical schemes.

The resulting distribution of Cretaceous calcareous nannofossils in the Cresmina Formation is given in Figure 3 and is calibrated to the zonation schemes of Sissingh $(1977,1978)$ and Applegate \& Bergen (1989). The Late Barremian to 'early' Late Aptian falls 


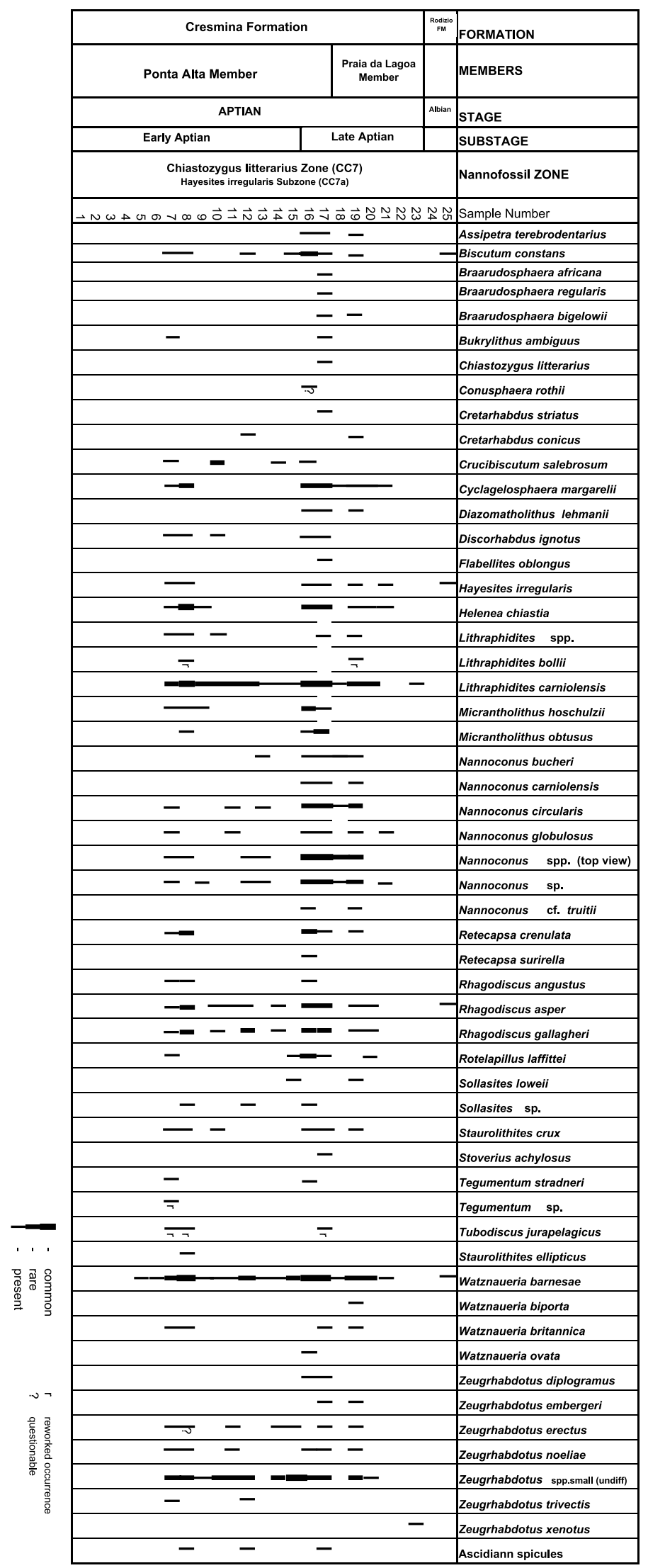

Fig. 3. Distribution of calcareous nannofossils in the S. Julião section, Cresmina Formation. 


\section{Ericeira/São Julião}
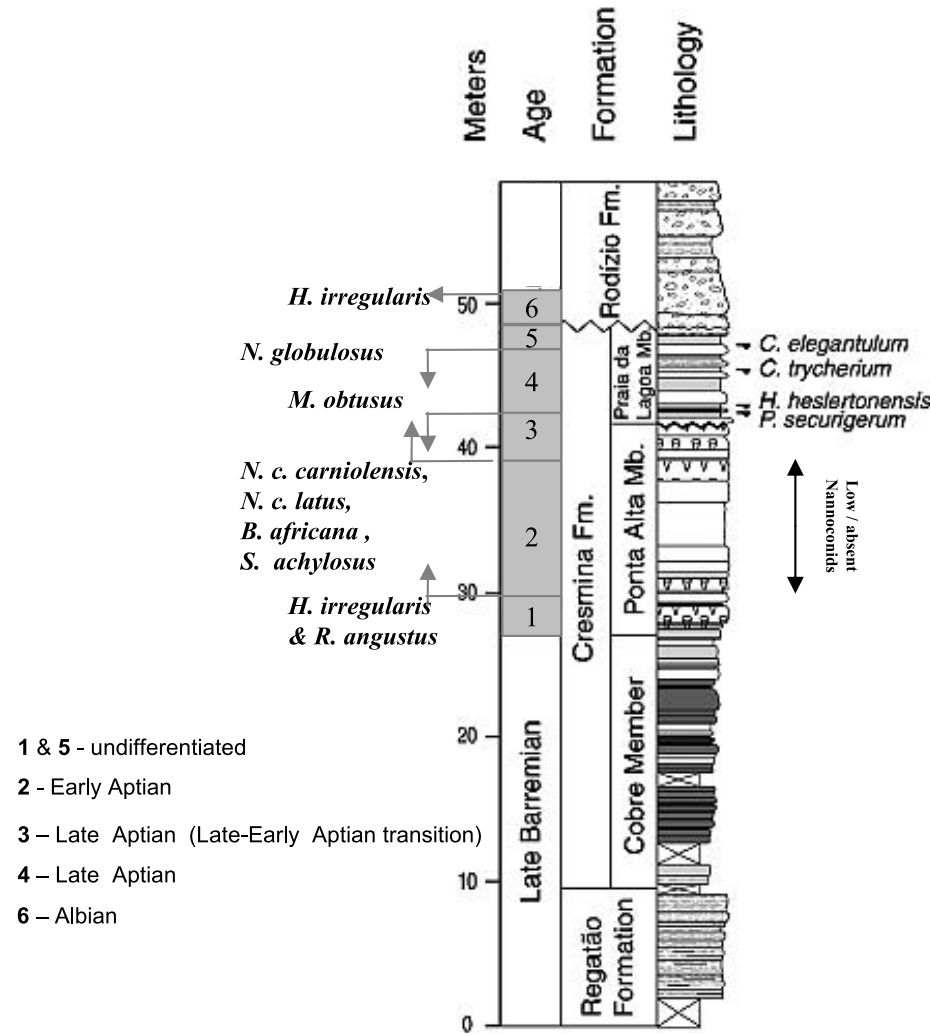

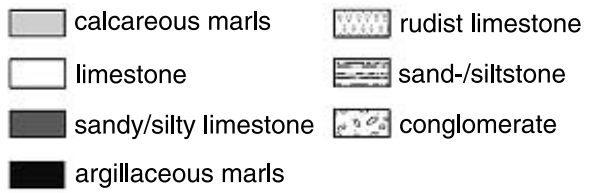

$\delta^{18} \mathrm{O}$ in [\%] VPDB

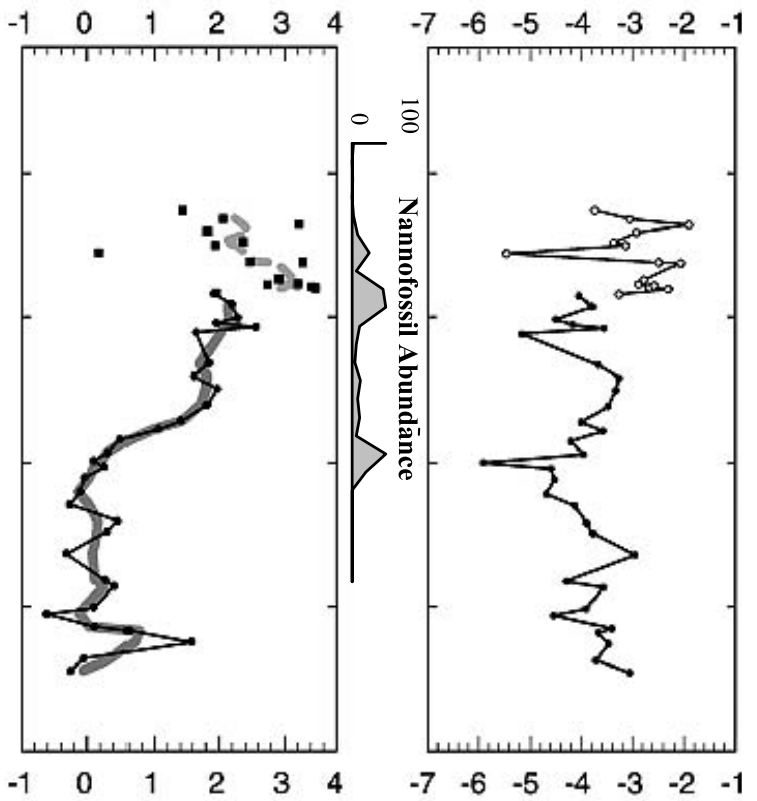

Fig. 4. Calcareous nannofossil biostratigraphy; integration with $\delta^{13} \mathrm{C}$ and $\delta^{18} \mathrm{O}$ anomalies after Burla et al., 2008.

within the Hayesites irregularis Subzone (CC7a) of the Chiastozygus litterarius (CC7) nannofossil Zone defined in the following section.

\section{Chiastozygus litterarius (CC7) nannofossil Zone}

\section{Hayesites irregularis Subzone (CC7a) of the Chiastozygus litterarius Zone (CC7)}

Definition. Interval from the first occurrence of Hayesites irregularis to the first occurrence of Eprolithus floralis.

Authors. CC7a: Thierstein (1971) amended by Manivit et al. (1977).

Remarks. This subzone was proposed by Thierstein (1971) and was used by Applegate \& Bergen (1989). In the latter, it was cited as an amendment from Manivit et al. (1977); however, no such amendment to the $\mathrm{CC} 7 \mathrm{a}$ subzone is referred to in that paper.

Age. CC7a: Early Aptian.

\section{RESULTS}

The majority of the samples analysed yielded extremely poor nannofossil assemblages most likely reflecting the shallow-marine depositional setting and a combination of dilution by clastic particles and post-depositional dissolution. The presence of smaller nannofossils with poor to moderate preservation suggests that dissolution was moderate. The continuous occurrence of abundant specimens of the benthic foraminifera Palorbitolina lenticularis in most of the sampled interval further supports this interpretation, indicating a shallow depositional environment. The opportunistic behaviour observed in the acmes of $P$. lenticularis indicates rapidly oscillating water masses within a high stress shallow-marine environment. Increases in nannofossil abundance and diversity may therefore provide evidence for transgressions within the succession.

Samples 1 to 6 of the Ponta Alta Member were barren of nannofossils. This interval coincides with the occurrence of a reefal limestone and reflects extremely shallow-marine/nearshore conditions.

A significant increase in nannofossil abundance and diversity is observed between samples 7,8 and 9 and coincides with the progressive passage from reefal limestone into Orbitolina marly limestone. Similar increases are observed in samples 16, 17 (corresponding to interbedded Orbitolina marls and limestones) and 19 (corresponding to marls but including the progressive passage to the Orbitolina calcareous marls).

The similarity between nannofossil assemblages recovered from samples 7, 8, 16, 17 and 19 suggests a very short time frame 

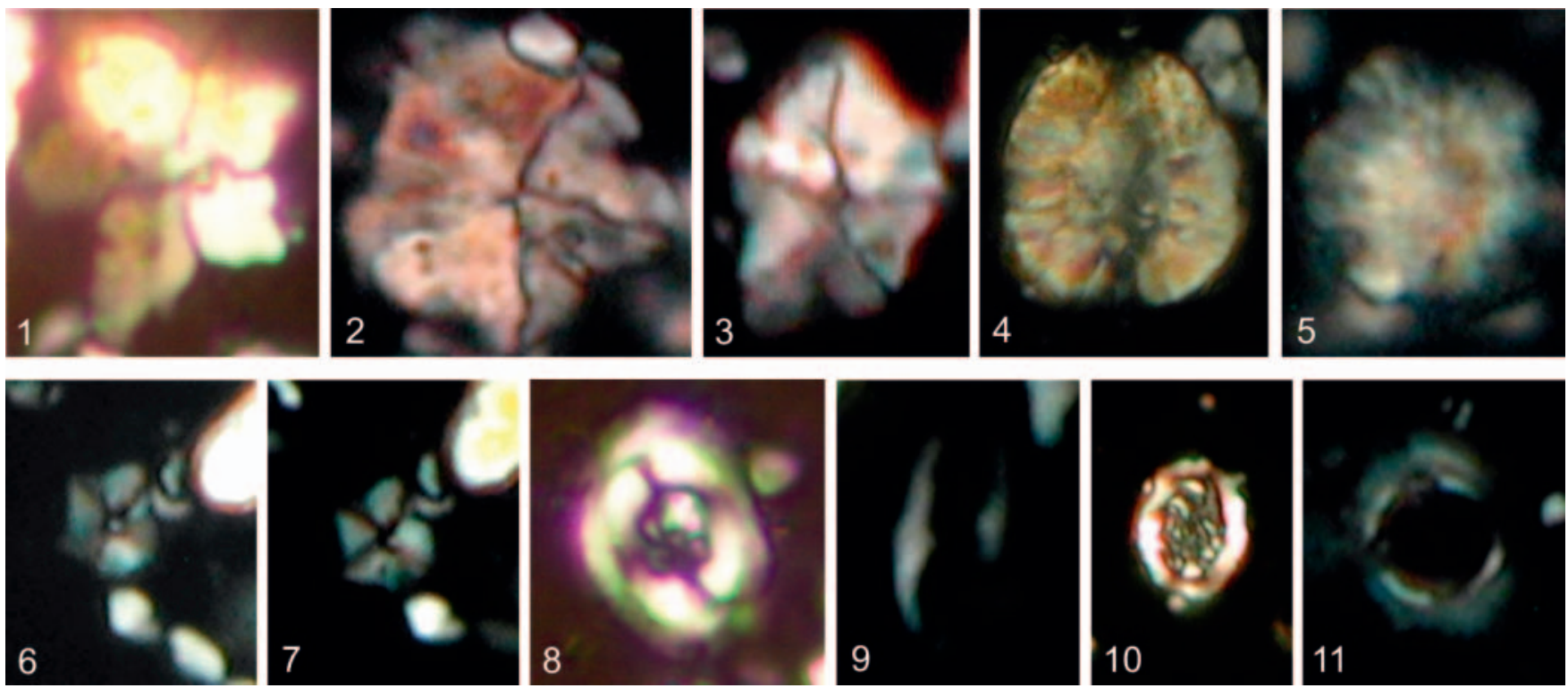

Explanation of Plate 1.

Magnification of $\times 2500$ for all specimens unless otherwise stated, 1, Braarudosphaera africana, sample 17; 2, 3, Micrantholithus obtusus, samples 16 \& 17; 4, Nannoconus globulosus, sample 17; 5, N. carmiolensis latus, sample 16; 6, 7, Hayesites irregularis, samples 7, $\times 3000 ; \mathbf{8}$, Flabellites oblongus, sample 17; 9, Rhagodiscus angustus, sample 7, ×3000; 10, Rhagodiscus asper, sample 8, ×3000; 11, Stoverius achylosus, sample 17, $\times 3000$.

for sediment deposition. The extremely rare occurrences of nannofossils between samples 9 and 15 and in samples 18 and 21-25 suggest either intense dissolution and/or re-occurrence of shallow-marine/restrictive environments. The extremely poor nannofossil recovery in sample 18 from the Praia da Lagoa Member and the subsequent occurrence of oyster-bearing limestones suggest the progressive onset of a regressive trend. This trend is also confirmed by the recovery of nannofossil-barren samples (samples 22 and 24) and of extremely poor nannofossil recovery in samples 21,23 and 25 .

The deposition of marls with moderately common nannofossil recovery (sample 19) either marks the last pulse of marine influence or reworking of the nannofossils prior to the deposition of the barren sandstones of the 'Grés superiores de Almargem' (Rodísio Formation)).

\section{BIOSTRATIGRAPHY}

The majority of the nannofossiliferous part of the section (samples 7-21) can be assigned to nannofossil Subzone CC7a (latest early Aptian-earliest late Aptian - we will use the term mid-Aptian for this designation), despite the absence of the principal marker species Eprolithus floralis throughout these assemblages. We suggest that the absence of this species may be due to ecological exclusion from these near-shore environments. The age determination is instead based upon the consecutive ranges of the marker taxa Hayesites irregularis and Micrantholithus spp., which occur through subzone CC7a, and the presence of Braarudosphaera africana, which has a first appearance within subzone CC7a (Herrle \& Mutterlose, 2003). The presence of Nannoconus carniolensis from sample 16 indicates a position towards the top of subzone CC7a, as its first appearance was previously reported at the base of the late Aptian (Deres \& Achéritéguy, 1980). A mid-Aptian age is also supported by the presence of Rhagodiscus angustus in sample 16 (Thierstein, 1971) and S. achylosus in sample 17 (Bralower et al., 1994).

These nannofossil-based age determinations are in good agreement with a recent carbon isotope record generated from this succession by Burla et al. (2008). This study documented a significant positive carbon isotope excursion within the Ponta Alta Member (Fig. 4) and considered this to be an expression of the Early Aptian OAE1a event, which, according to Larson \& Erba (1999), Leckie et al. (2002) and Erba (2004), terminates within nannofossil subzone CC7a. Although nannofossils are generally rare within these sediments it may be significant that nannoconids are essentially absent within the lower half of the Ponta Alta Member that coincides with the OAE 1a carbon isotope excursion. Elsewhere, a significant decline in nannoconid abundance has been shown to coincide with this OAE (the nannoconid crisis of Erba, 2004).

The increase in the recovery of nannoconids in samples 16 and 17 in the upper Ponta Alta Member (Fig. 4) coincides with a further increase in the $\delta^{13} \mathrm{C}$ isotope values and may be an indication that this part of the section lies above the nannoconid crisis interval. According to Erba (2004), the return of nannoconids coincides with the highest values of the $\delta^{13} \mathrm{C}$ isotope anomaly and with the transition between the L. cabri and $G$. ferreolensis planktic foraminiferal zones in the earliest Late Aptian.

The upper part of the Praia da Lagoa Member was left undifferentiated due to a sharp decrease in nannofossil recovery, including barren samples and the absence of age-diagnostic taxa. This trend clearly suggests the onset of shallow-marine/ restrictive environments with the deposition of oyster limestones, marls, sandy marls and dolostones.

The re-occurrence of Hayesites irregularis in the Rodizio Formation indicates an age not older than the Albian for these sediments (Bown et al, 1998). 


\section{DISCUSSION}

A late Early Aptian age is clearly supported by the nannofossil results for most of the Ponta Alta Member. However, the transition between the Ponta Alta and Praia da Lagoa members (samples 16 and 17) is indicated by nannofossil to be in Late Aptians age.

The results obtained by Rey (1972), Cabral \& Colin (1998), Pereira \& Cabral (2005) and Heimhofer et al. (2007) suggest a latest Early Aptian age for the whole Praia da Lagoa Member. In this study, the last record of $M$. obtusus, together with the first record of $B$. africana, S. achylosus and $N$. carniolensis, indicates a slightly younger age within the earliest Late Aptian for the topmost Ponta Alta Member. In addition, the increase in the recovery of nannoconids (including the first record of $N$. carniolensis) observed in samples 16 and 17 also support a slightly younger position above the late Early Aptian 'nannoconid crisis' event. Heimhofer et al. (2007) assigned an Early Aptian age for these sediments; however, the age assignment was based on sporadic occurrences of long-ranging marker fossils and no abundance data were provided.

The nannofossil results indicate the presence of Barremian reworking in the assemblages from the Praia da Lagoa Member (Tubodiscus jurapelagicus and Lithraphidites bollii occurrences in samples 17 and 19) and, therefore, we place more confidence in the first occurrence of datums.

\section{CONCLUSIONS}

The biostratigraphical study of calcareous nannofossils from the Cresmina Formation (Lusitanian Basin) provides further evidence for calibrating the age of these sediments and the regional isotope stratigraphy. There is in good agreement with the previous age assignments for most of the Ponta Alta Member and Rodízio Formation, but the nannofossil data indicate an earliest Late Aptian age for the transition between the Ponta Alta and Praia da Lagoa members and a similar age for the remainder of the Praia da Lagoa Member.

The integration of the nannofossil results herein with the isotope stratigraphy of Burla et al. (2008) for the same section (Fig. 4), and the comparison with open-marine sections (Burla et al., 2008, fig. 11) in the same study, provides calibration points and increases the confidence level placed in the age determinations. In this context the use of the isotope stratigraphy in conjunction with the biostratigraphy in wider geographical areas and in short-term correlations across different depositional environments can add confidence in local age determinations.

\section{ACKNOWLEGEMENTS}

The authors would like to acknowledge Liam Gallagher and Matthew Hampton for discussions on the taxonomy and general advice. Thanks also go to Shirley Van Heck, Iain Prince, John Bennett and John Gregory for general advice and editing and to Jens Herrle and Osman Varol for the revisions, advice and support (in particular to Jens Herrle whose comments shaped the final version of this publication).

\section{Manuscript received 21 May 2008 Manuscript accepted 25 September 2009}

\section{REFERENCES}

Applegate, J.L. \& Bergen, J.A. 1989. Cretaceous calcareous nannofossil biostratigraphy of sediments recovered from the Galicia margin, ODP
Leg 103. In: Boillot, G., Winterer, E.L. et al. (Eds), Proceedings of the Ocean Drilling Program, Scientific Results, 103: 293-326.

Berthou, P.Y. 1973. Le Cénomanien de L'Estremadure portugaise. Memórias dos Serviços Geológicos de Portugal, 23(N.S.): 1-169.

Berthou, P.Y. 1984. Résumé synthétique de la stratigraphie et de la paléogéogéoghaphie du Crétacé moyen et supérieur du bassin occidental portugais. Geonovas, 7: 99-120.

Berthou, P.Y. \& Hasenboehler, B. 1982. Les kistes de dinoflagellés de l'Albien et du Cénomanien de la région de Lisbonne (Portugal). Répartition et intêret stratigraphique. Cuadernos Geologia Ibérica, 8: 761-779.

Berthou, P.Y. \& Leereveld, H. 1986. L'Apport de l'étude des kistes de dinoflagellés à la stratigraphie des terrains Hauteriviens à Albiens. Région de Lisbonne (Portugal). Comunicações dos Serviços Geológicos de Portugal, 72(1): 119-128.

Berthou, P.Y. \& Leereveld, H. 1990. Stratigraphical implications of palynological studies on Berriasian to Albian deposits from western and southern Portugal. Review of Palaeobotany and Palynology, 66: 313-344.

Berthou, P.Y., Hasenboehler, B. \& Moron, J.M. 1981. Apports de la Palynologie à la Stratigraphie du Cretacé moyen et supérieur du Bassin Occidental Portugais. Memórias e Notícias, Publicações do Museu e Laboratório Mineralógico e Geológicos, Universidade de Coimbra, 91-92: 183-221.

Bown, P.R. \& Young, J.R. 1998. Techniques. In: Bown, P.R. (Ed.), Calcareous nannofossil biostratigraphy, 16-28. Chapman \& Hall/ Kluwer Academic Publishers, London.

Bown, P.R., Rutledge, D., Crux, J.A. \& Gallagher, L.T. 1998. Lower Cretaceous. In: Bown, P.R. (Ed.), Calcareous nannofossil biostratigraphy, 86-131. Chapman \& Hall/Kluwer Academic Publishers, London.

Bralower, T.J., Arthur, M.A., Leckie, R.M., Sliter, W.V., Alard, D.J. \& Schlanger, S.O. 1994. Timing and Paleoceanography of Oceanic Dysoxia/Anoxia in the Late Barremian toEarly Aptian (Early Cretaceous). Palaios, 9: 335-369.

Burla, S., Heimhofer, U., Hochuli, P.A., Weissert, H. \& Skelton, P. 2008. Changes in sedimentary patterns of coastal and deep-sea successions from the North Atlantic (Portugal) linked to Early Cretaceous environmental change. Palaeogeography, Palaeoclimatology, Palaeoecology, 257: 38-57.

Cabral, M.C. \& Colin, J.-P. 1998. Nouvelles espèces de Limnocytheridae (ostracodes limniques) dans l'Aptien du Portugal: systématique et paléoécologie. Revue de micropaléontologie, 41(4): 269-279.

Choffat, P. 1885. Recueil de monographies stratigraphiques sur le Système Crétacique du Portugal. lère étude: contrées de Cintra, de Bellas et de Lisbonne. Mémoires Section des Travaux Géologiques du Portugal, Lisboa, $68 \mathrm{pp}$.

Deres, F. \& Achéritéguy, J. 1980. Biostratigraphie des nannoconide's. Bulletin des Centres de Recherches Exploration Production Elf Aquitaine, 4: 1-53.

Dinis, J.L. \& Trincão, P. 1995. Recognition and stratigraphical significance of the Aptian unconformity in the Lusitanian Basin, Portugal. Cretaceous Research, 16: 171-186.

Erba, E. 2004. Calcareous nannofossils and Mesozoic oceanic anoxic events. Marine Micropaleontology, 52: 85-106.

Hasenboehler, B. 1981. Etude paléobotanique et palynologique de l'Albien et du Cénomanien du Bassin occidental portugais au sud de l'accident de Nazaré (Province d'Estremadura, Portugal). Mémoires Sciences de la Terre, 81(29): 1-317.

Heimhofer, U., Hochuli, P.A., Burla, S. \& Weissert, H. 2007. New records of Early Cretaceous angiosperm pollen from Portuguese coastal deposits: Implications for the timing of the early angiosperm radiation. Review of Palaeobotany and Palynology, 144: 39-76.

Herrle, J.O. \& Mutterlöse, J. 2003. Calcareous nannofossils from the Aptian-early Albian of SE France: Paleoecological and biostratigraphic implications. Cretaceous Research, 24:1-22.

Larson, R.L. \& Erba, E. 1999. Onset of the mid-Cretaceous greenhouse in the Barremian-Aptian: Igneous events and the biological, sedimentary, and geochemical response. Paleoceanography, 14(6): 663-678.

Leckie, R.M., Bralower, T.J. \& Cashman, R. 2002. Oceanic anoxic events and plankton evolution: biotic response to tectonic forcing 
during the mid-Cretaceous. Paleoceanography, 17, DOI: 10.1029/ 2001PA000623.

Manivit, H., Perch-Nielsen, K., Prins, B. \& Verbeek, J.W. 1977. Mid Cretaceous Calcareous nannofossil biostratigraphy. Proceedings of the Koninklijke Nederlandse Akademie Van Wetenschappen Series B-Palaeontology Geology Physics Chemistry Anthropology, 8: 169191.

Pereira, R. \& Cabral, M.C. 2005. Charophytes from the Lower Aptian of Rio de Mouro (Lisbon region, Portugal). Revista Española de Micropaleontologia, 37(1): 171-181.

Ramalho, M.M. 1971. Contribution à l'étude micropaléontologique et stratigraphique du Jurassique supérieur et du Crétacé inférieur des environs de Lisbonne (Portugal). Memórias dos Serviços Geológicos de Portugal, 19(N.S.): 1-212.

Rey, J. 1972. Recherches géologiques sur le Crétacé inférieur de l'Estremadura (Portugal). Memórias dos Serviços Geológicos de Portugal, 21(N.S.): 1-477.
Rey, J. 1979. Le Crétacé inférieur de la marge atlantique portugaise: biostratigraphie, organisation séquentielle, évolution paléogéographique. Ciências da Terra, 5: 97-120.

Rey, J. 1984. Mégaséquences et séquences élémentaires du Crétacé inférieur portugais. Volume d'hommages à G. Zbyzsewski. CNRS Ed. Recherches sur les Civilisations, 87-99.

Rey, J. 1992. Les unités lithostratigraphiques du Crétacé inférieur de la région de Lisbonne. Comunicações dos Serviços Geológicos de Portugal, 78(2): 103-124.

Sissingh, W. 1977. Biostratigraphy of Cretaceous calcareous nannoplankton. Geologie en Mijnbouw, 56(1): 37-65.

Sissingh, W. 1978. Microfossil biostratigraphy and stage-stratotypes of the Cretaceous. Geologie en Mijnbouw, 57: 433-440.

Thierstein, H.R. 1971. Tentative Lower Cretaceous calcareous nannoplankton zonation. Eclogae Geologicae Helvetiae, 64: 459-488. 